\title{
The Squatters' Movement in Europe: A Durable Struggle for Social Autonomy in Urban Politics
}

\author{
Miguel A. Martínez López \\ Departamento de Sociología II, Facultad de Ciencias Políticas y Sociología, Universidad \\ Complutense de Madrid, Madrid, Spain; \\ miguelam@cps.ucm.es
}

\begin{abstract}
Squatting empty properties for living or to develop public activities has lasted in European cities for more than three decades. Although local and national contexts differ significantly, there are also some general trends and patterns that deserve careful attention. When squatting occasionally appears in public debates, controversy is generated and many gaps open between academic, social and political perceptions. In this article I use evidence from several European cities to argue that the squatters' movement has produced an original impact in urban politics. The main feature of this impact has been to generate a relatively wide autonomous and mainly non-institutional mode of citizen participation, protest and self-management. How has this been possible? Which are the specific contributions made by this urban movement? These are questions that both scholars and activists continuously claim to be relevant, so that this research attempts to offer some general answers based on detailed comparisons and experiences.

Resumen: La okupación de inmuebles vacíos para residir o para desarrollar actividades públicas en ellos se ha prolongado en las ciudades europeas durante más de tres décadas. Aunque los contextos locales y nacionales difieren significativamente, existen también algunas tendencias y pautas generales que merecen una detallada consideración. Cuando la okupación aparece ocasionalmente en los debates públicos, es habitual que genere mucha controversia y percepciones académicas, sociales y políticas muy distintas. En este artículo utilizo la evidencia disponible en varias ciudades europeas para sostener que el movimiento de okupaciones ha producido un impacto original en la política urbana. La principal característica de ese impacto es la apertura de un modo de participación ciudadana, de protesta y de autogestión con una relativamente amplia autonomía al margen de las instituciones. ¿Cómo ha sido posible ese desarrollo? ¿Cuáles son las contribuciones específicas realizadas por este movimiento urbano? Estas son las cuestiones que tanto investigadores/as como activistas han considerado a menudo como relevantes, de tal modo que el presente texto intenta ofrecer algunas respuestas generales a partir de comparaciones y experiencias concretas.
\end{abstract}

Keywords: squatting, urban movements, urban politics, Europe

Palabras clave: okupación, movimientos urbanos, política urbana, Europa

\section{Introduction}

The occupation of empty buildings and houses to satisfy housing needs or to develop social activities, has been a widespread practice all over Europe since the 1970s, although it also occurred occasionally in the past (Bailey 1973; Colin 2010, Wates and Wolmar 1980). Various authors identified this wave of squatting during the last four decades as a new urban movement (Lowe 1986; Martínez 2007; Pruijt 2003; 
Ruggiero 2000) rather than as isolated social practices characterised according to the following: its mostly illegal nature (squatting as a violation of private property); the subcultural aspects of squatters' dress, discourse and lifestyle; and exclusively involving youngsters.

In the next sections I shall describe some of the most salient features of the squatters' movement to distinguish it from other urban movements. An early transnational orientation and regular connections among squatters all over Europe indicate broader motivations than those of the movements exclusively attached to local politics. As a matter of fact, political radicalism (made up of leftist, autonomist and libertarian principles) has fed multiple fields of expression and protest beyond the squatting of empty buildings. The strong emphasis that squatters put on their autonomous way of involvement in urban politics and affairs (Katsiaficas 2006) will be referred to as a crucial contribution to the experience of urban movements.

Instead of looking at the specific unintended consequences of squatting in some processes of urban renewal and gentrification (Holm and Kuhn 2010; Uitermark 2004a), or at other internal contradictions in terms of segregation, the reproduction of inequalities and the tendencies to self-ghettoisation (Adilkno 1994 [1990]; Aguilera 2010; Lowe 1986; Martínez 2002; Owens 2009), in this paper I will explain the development of European squatting as a paradigmatic autonomous urban movement according to two basic sets of socio-spatial relations. On the one hand, I will focus on the conditions of possibility that mainly made squatting possible. On the other hand, I will discuss the most prominent social benefits, among other impacts, squatting has produced (and still produces) for both the people involved and for urban politics in general.

The purpose of this research is to identify general trends and similar socio-spatial dynamics among the experiences of squatters in different European cities. Given the constraints of the present synthetic account, I do not pretend to draw a full picture of squatting in Europe, although a systematic comparison of particular aspects had been necessarily underlying this endeavour. Far away from avoiding a critical approach to squatting, the emphasis on those two specific questions is due to the political debates currently going on in different countries-these facing either the last attempts to ban squatting where it was legal (the Netherlands and the UK) or the persistent initiatives of squatting where it remains illegal. ${ }^{1}$

As we shall see later, squatting as a movement involves mainly the constitution of squatted social centres and (usually collective) squatted homes in urban settings, though rural and occasional squatting are sometimes closely related to the former. Previous research (Pruijt 2004a) has distinguished five general types of squatting ${ }^{2}$ in which "political squatting" appears as only one of the possible configurations. In this paper I try to go a step further. By focusing on the particular beneficial impacts of squatting I suggest that they can be achieved, with different proportions and combinations, at any general type of squatting. In addition, I consider that the squatted social centres had played a key political role in the squatting movement of any European city in which squatting has been relevant. This means that they served as an essential socio-spatial infrastructure for the coordination and public expression of the squatting movement as a political urban agent, although some non-squatted social centres helped squatting at large too. Nonetheless, I contend 
that squatted houses just for living were also basic resources for many activists or turned dwellers into activists, thus establishing political networks able to assemble the different configurations of squatting.

A short remark on methodology: I have been researching squatting since 1998 (initially in Spain, but also in many European cities over the years), collecting documents, interviewing activists, attending activities in squats and participating myself as an activist in several squatted social centres. I contributed to launch the activist-research network SqEK (Squatting Europe Kollective) which started to hold meetings in 2009 and is still very active after seven encounters (Madrid, Milan, London, Berlin, Paris, Amsterdam and Copenhagen). This group includes more than 50 members with different profiles. The research carried out by SqEK is presented and discussed at the regular meetings, which are also excellent opportunities to visit local squats, to talk to activists and to gain more knowledge about specific stories and circumstances. The first publication of SqEK was both a political manifesto and a research agenda (www.acme-journal.org/vol9/SQEKeng2010.pdf), and the group is also promoting the distribution of articles around squatting. The SqEK meetings provided me with the contrast of data and interpretations of squatting with other scholars and activists across Europe. My present depiction of a few patterns of the squatters' movement in European cities partially stems from this inspiring activist, theoretical and fieldwork experience.

This research is based on scholarly works as well as self-produced documents of squats, mass media information and my own collection of experiences, discourses and observational data. This account, therefore, relies on this broad and mostly qualitative information (primary and secondary), so the distinctions and analysis that I suggest might be improved by further systematic comparisons.

\section{Squatting as an Urban Movement}

As an urban movement, squatting began to grow in European countries like the Netherlands, Germany, the UK, France, Switzerland and Italy from the late 1960s and early 1970s onwards. Despite particular cycles of evolution in different cities, the tide of squatting rolled through other countries in the coming decades, such as Denmark, Spain, Greece and Poland. There is good evidence (Herreros 2004; Koopmans 1995; Martínez 2002; Pruijt 2004a) that this expansion was due to transnational imitation and multiple personal connections, which constituted diffuse social and political networks.

Since the 1980s, political meetings took place with the attendance of squatters from several countries. These events were continuously replicated during the 1990s and 2000s. For instance, in June 2010, an activist conference called "European Squatting Meeting" was held in Barcelona, basically facing comparative and crosscountry legal issues. During public debates Spanish squatters described how they frequently travelled to Germany and Italy early after Dutch squatters came to Madrid in the mid 1980s to talk about their experiences and to show their selfmade videotapes. "International diffusion" is also claimed by Koopmans (1995:171), who argued that there was an increase in squatting in West German cities after the riots around squatted buildings in Amsterdam and Zurich were widely 
publicised. Since 1997, international email lists and websites, such as squat.net and indymedia centres, provided immediate tools of communication among the European squatters.

These activists would easily fit what Tarrow (2005) called "rooted cosmopolitans", even before the times of cheap flights and the wave of protests in the no-global summits. For example, The No Olympics Games Committee (Nolympics) promoted by Amsterdam's squatters successfully opposed the city government's plans for 1992 (Adilkno 1994 [1990]:129-147; Owens 2009:238). A few years after the Zapatista uprising in México, in 1994, Spanish and Italian squatted social centres organised international encounters and debates against neoliberal policies, in support of that new alter-global indigenous movement. Since 2005, the Intersquat Festival was promoted by Paris' squatters and artists with an explicit European scope. As a consequence, it has been imitated in Berlin and Rome, in spite of the absence of proper illegal squats in the former city. The activist-research network SqEK also contributed to gather people interested or involved in squatting, and to promote self-reflective and public debates about this issue. Above all, travelling around and being hosted in squats all over Europe have been the most usual behaviours of activists to keep alive an informal network of mutual learning and help, without losing the local roots of the everyday practices of squatting. Christiania in Copenhagen, for instance, offered free temporary residence to worldwide activists willing to research any branch of squatting (Thörn, Wasshede and Nilson 2011).

Since the seminal work of Castells (1983), debates on the definition of urban movements have been ongoing (Mayer 2003, 2006; Pickvance 2003). While Castells emphasised the effects of movements on "structural social change" and "urban meaning", other authors focused more on constraints coming from a wider context, such as organisational resources and internal dynamics (Fainstein and Hirst 1995; Pickvance 1985, 1986; Villasante 1984). According to Pruijt (2007:5115), for example, "urban movements are social movements through which citizens attempt to achieve some control over their urban environment. The urban environment comprises the built environment, the social fabric of the city, and the local political process." Furthermore, urban movements "participate actively in urban policies and may do so in relation to any public policy in specific parts of the city or at municipal, metropolitan or regional level, although their effects or mutual articulation may have national or international scope" (Martínez 2011:154).

What are, then, the main features of squatting as an urban movement? First, squatting of empty buildings encompasses both hidden and visible actions in the eyes of neighbours, mass media and authorities. The latter emerge when a set of organised groups makes public claims for the legitimacy of squatting-banners and flags on the walls, or leaflets distributed to neighbours are frequent indicators. Both long-lasting political organisations for whom squatting is a central struggle and coordination platforms set up by squats at city-wide or district levels are also proof of the consistency of social networks linking squatters with each other. In addition, many invisible squatters are helped by political activists and make use of informal ties that allow them to squat, remain, and oppose threats of eviction. Second, beyond the immediate satisfaction of squatters' material needs, a more general political frame underlies every wave of squatting initiatives. According to this 
frame, squatting challenges housing shortages, urban speculation, absolute private property rights, and the capitalist production of urban space as it is conducted by the State and private interests. Thus, squatting fits into the broad category of left-libertarian social movements (Della Porta and Rucht 1995).

Squatting is an urban movement in which there is a close connection between a broad range of political activities (meetings, demonstrations, direct actions, campaigning, etc) and a practical development of collective self-management on many dimensions of life. These include the rehabilitation of buildings, the sharing of food and various resources, the ethics of do-it-yourself and mutual aid, the promotion of counter-cultural expressions and radical left ideas, etc (McKay1998; Notes from Nowhere 2003). This connection indicates the constitution of a persistent autonomous and radical urban movement with a pragmatic orientation, although some institutional bonds and constraints can also play a significant role in its expansion.

Strong repression and generalised attempts to legalise squats, for instance, can reduce the autonomy and radicalism of the squatters' movement (Mikkelsen and Karpantschof 2001). Privatisation and outsourcing of collective consumption can also threaten the influential model of self-organisation at squatted social centres, this being one of the main lines of internal division among Italian squatters (Membretti 2007; Moroni and Aaster 1996). According to Castells (1983:322), autonomy means, basically, a neat separation of activists from institutionalised actors like political parties and unions. This also implies serious attempts to set up both movements' own cultural identity and political, local, decentralised, and self-managed institutions. Movements' ideological and organisational autonomy cannot avoid connection to the society at large through some institutional actors, professionals and communication media. Since some authors have criticised the term "autonomy" because is charged with the burden of a liberal and individualistic affiliation (Bookchin 1998), the expression "social autonomy" can still preserve the emphasis on the dialectic dependence of individuals upon society, and vice versa, which is familiar to "social anarchism" as the setting up of an anti-capitalist urban communities of equals (Bookchin 1998; see also Graeber 2004:2, 65-66). Social autonomy also recalls the Italian Operaist refusal of an institutional representation of class struggles (Mitropoulos 2007), the Situationists' claims for a total participation in urban affairs (Knabb 1997), and the Autonomist organisations with a left-libertarian orientation who practised squatting as one of their preferred political arenas to challenge the post-fordist capitalism (see, for example, Adilkno 1994 [1990]; Koopmans 1995; Mikkelsen and Karpantschof 2001; Wilhelmi 2000). Katsiaficas (2006:14-16) has brilliantly explained the tipping point that European autonomous movements represented in comparison to the New Left and extra-parliamentary politics around 1968:

By 1980, a movement existed which was clearly more radical and bigger than that the sixties. The new movement was more diverse and unpredictable and less theoretical and organized than was the New Left. Despite their differences, they shared a number of characteristics: anti-authoritarianism; independence from existing political parties; decentralized organizational forms; emphasis on direct action; and combination of culture and politics as means for the creation of a new person and new forms for 
living through the transformation of everyday life ... More than anything else, the new radicals are distinguished from the New Left by their orientation to themselves - to a "politics of the first person" —not to the "proletariat" or the "wretched of the earth" ... In contrast to the centralized decisions and hierarchical authority structures of modern institutions, autonomous social movements involve people directly in decisions affecting their everyday lives. They seek to expand democracy and to help individuals break free of political structures and behavior patterns imposed from the outside. Rather than pursue careers and create patriarchal families, participants in autonomous movements live in groups to negate the isolation of individuals imposed by consumerism. They seek to decolonize everyday life.

I agree with Katsiaficas' definition of autonomy, which also includes "direct-democratic forms of decision-making", "self-managed consensus" and "spontaneous forms of militant resistance" to domination in all the domains of life, society and politics (Holloway 2006). These principles expanded from the experience of squatters as well as from the new feminist and anti-nuclear movements which appeared in Europe during the 1980s. Later on, Zapatistas' uprisings, alterglobalisation struggles and, recently, "occupy the squares" movement follow similar insights.

Squatting can also be understood as an immediatist struggle in the sense that Foucault means it:

In such struggles people criticize instances of power which are the closest to them, those which exercise their action on individuals. They do not look for the 'chief enemy' but for the immediate enemy. Nor do they expect to find a solution to their problem at a future date (that is, liberations, revolutions, end of class struggle) (Foucault 1982:780).

Squatting is, above all, direct action aimed to satisfy a collective need through social disobedience against the oppressive protection of property rights. The mostly temporary appropriation of abandoned spaces is a partial attack on the unjust distribution of urban goods, but it is also a grassroots political intervention at the core of urban politics. Squatters defy the rules of the urban growth machine both for the sake of their own needs and to promote citizens' protests that can be easily imitated until the last vacant space is reclaimed by those who are dispossessed (Alford and Friedland 1985; Piven and Cloward 1979; Vitale 2007).

\section{What Makes Squatting Possible?}

The aim of this section is to identify some of the most relevant socio-spatial conditions of possibility for the occurrence and development of squatting. They are summarised in Table 1 but none of them can be understood without regarding the historical and spatial contexts in which they exist and, simultaneously, can be interpreted and used as opportunities (or constraints) by individuals and groups. Political experience, cultural differences and material conditions of living enable squatters with all kind of resources to act within these structural frameworks. Thus, each one of the following conditions of possibility demands specific analysis on its own and how it interacts with the others in order to be regarded as both necessary and sufficient. For example, the cases of squatting in contexts where there is no critical housing shortage, like Gothenburg (Thörn 2008) and Vienna 
Table 1: What makes squatting possible?

\begin{tabular}{|c|c|c|}
\hline $\begin{array}{l}\text { Conditions } \\
\text { of possibility }\end{array}$ & $\begin{array}{c}\text { Specific } \\
\text { favourable conditions }\end{array}$ & $\begin{array}{l}\text { Underlying } \\
\text { advantages }\end{array}$ \\
\hline Empty/abandoned properties & $\begin{array}{l}\text { Not too damaged nor too } \\
\text { defended }\end{array}$ & $\begin{array}{l}\text { Vacant spaces not used for } \\
\text { speculative purposes }\end{array}$ \\
\hline $\begin{array}{l}\text { Urban renewal and } \\
\text { restructuring }\end{array}$ & Slow rhythm & Neighbours as allies \\
\hline $\begin{array}{l}\text { Light or permissive legal } \\
\text { framework }\end{array}$ & $\begin{array}{l}\text { Not too restricted nor } \\
\text { repressive }\end{array}$ & Defence of housing rights \\
\hline $\begin{array}{l}\text { Connection to other social } \\
\text { movements }\end{array}$ & Local and global claims & $\begin{array}{l}\text { Multiple goals, alliances and } \\
\text { legitimacy }\end{array}$ \\
\hline $\begin{array}{l}\text { Independent and mass media } \\
\text { coverage }\end{array}$ & Not too aggressive (the latter) & $\begin{array}{l}\text { Evidence and examples of } \\
\text { autonomy }\end{array}$ \\
\hline
\end{tabular}

Source: author

(see the recently evicted Epizentrum: http://epizentrum.noblogs.org/) need to be explained more according to some conditions (for instance, alter-globalisation and anti-neoliberal ideology, or autonomy from the control of the State and political parties) than others.

Above all, squatting consists of a set of collective actions aimed to use empty or abandoned properties for housing purposes and/or for the promotion of social activities. The kind of respective owner and the duration of vacancy vary. The important condition here is the existence of a sufficient amount of buildings able to be occupied directly or after light works of rehabilitation. Squatters tend to do serious research on the specific legal and economic situation of each, apparently in disuse, building. Frequently, neighbours are the best source of information. Higher proportions of vacancy correlate with several factors apart from the otherwise indispensable activists' wishes: economic crisis and slumping construction, reduction in rental housing stock, privatisation of formerly public houses, increasing levels of private ownership of housing, changes of use in specific buildings, decline of industrial activities, urban renewal processes, etc. Accordingly, the opportunities for squatters seeking a place depend upon these macro dynamics to provide a quantity of effective spaces ready to be squatted.

Fortunately for squatters, capitalist urban speculation is based, among other things, on a convenient stock of empty buildings which allows owners to delay works or sales for a certain period of time, while negotiating the better price. The ideal speculator wants his or her ownership to be renewed, sold or rented at the highest price and at the earliest moment, but he/she can wait a certain period of time if there is an expected-relatively high-profit to gain. Only if there was a total occupation of the built environment in a given moment, without any loss or waste of owned space, would squatting be impossible. Quite the contrary, that ideal situation never occurs and permanent black holes within private and public real-estate markets are usually protected by property laws. As a consequence, all the information that squatters obtain about that essential gap and tensions within the process of capitalist accumulation (Harvey 1985:150) will open a window for going ahead with squatting actions (Martínez 2004; Péchu 2006). 
The profitable management of vacancy is only one of the possible sources of urban speculation, but the most direct source that squatters can fight against. This does not imply that the simple increase in the stock of vacant buildings, as is the case in the so-called shrinking cities, will determine the emergence of a squatting movement. If homeless population and organised activists are also diminishing, the likelihood of squatting will decrease. Moreover, the indispensable availability of empty properties to be occupied should be constructively intertwined with the lack of effectiveness of police repression and the previous political experience of potential squatters. For example, in Valencia (Spain) one old neighbourhood (Cabanyal) under threat of a very contested renewal operation had a lot of empty houses but the wave of squatting in that area only started once the neighbours firmly opposed the city plans and, at the same time, the evictions of squatters were effective in other parts of the city, such as the now rehabilitated historical centre with less evident vacancy (Collado 2007). Private defence of empty buildings has also developed as a very profitable business, not only for traditional companies of surveillance and private guards, but also for the new anti-squat companies who were born in the Netherlands during the 1990s (Buchholz 2011). These prevent squatting through the allocation of renters who pay a low prize but lack the conventional rights of renters so that they are forced to leave at any moment, whenever the owner requests.

The crucial condition of emptiness often depends upon urban planning and restructuring of specific areas. Displacement of industrial factories, vacant schools or public facilities which have moved to a different location, residential units subject to new regulations, all often occur when a whole area has been designed for accomplishing new functions. Authorities, planners and investors would argue that old-fashioned areas, poverty, crime, ruins, substandard housing and pollution demand a transformation of public space and, simultaneously, of the residential buildings and existing population therein. New roads or mega projects (like museums, stadiums, waterfronts, commercial malls, etc) may also account for the elite-driven vacancy of a large number of dwellings in a particular urban area (Fainstein $1994^{3}$ ). The slower the rhythm of these reconfigurations, the higher the opportunities for squatting and campaigning against the plans. Old owners and tenants appear as the natural allies of squatters opposing the authoritarian (or even the restricted participatory) manner of these urban interventions.

Many of the experiences of squatting in the late 1970s in Milano (Martin and Moroni 2007:178) and Berlin (Holm and Kuhn 2010; Mayer 1993) took place in working class and industrial areas where different political groups beside the squatters (tenants, countercultural artists, environmentalists, autonomist and libertarian organisations, etc) confronted the official urban plans. Old schools that did not suit the new regulations in Spain in the early 1990s were one of the favourite and more feasible targets of squatters in Spain during that period (Martínez 2004). In former industrial areas like Bilbao, before and after "the Guggenheim effect", many factories and residential buildings around them were widely squatted since the mid 1980s. One famous case has been the social centre and houses of Kukutza, an abandoned industrial building which was located in the popular neighbourhood of Rekalde (Bilbao) and was evicted in 2011 after 13 years of squatting while enjoying great social support (http://kukutza.blogspot.com/). 
Concerning the legal issues, there are, theoretically, three options: strong criminal persecution; light criminal persecution; and specific legal requirements that permit squatting occasionally. When the first option applies and authorities ${ }^{4}$ work hard to implement that legislation, squatting becomes too difficult, marginal and infrequent, although not absolutely impossible. Denmark, Germany and Sweden, for example, are the national contexts where this policy rules. However, it is important to note that the squatted community of Christiania in Copenhagen survived in a difficult environment where almost all squatting was repressed without concessions (Fox 2010; Hellström 2006; Mikkelsen and Karpantschof 2001; Thörn, Wasshede and Nilson 2011). In Germany the squatters' movement gained great strength during its first phases, and could preserve part of its radical identity and self-managed practices after waves of either hard repression or comprehensive negotiation took place (in the early 1980s in general and in the early 1990s also in Berlin) (Holm and Kuhn 2010; Mayer 1993; Sabaté $2009^{5}$ ). Legislation and quick repression of attempts to squat have prevented the emergence of a squatters' movement in Sweden where, notwithstanding, social housing was easily accessible for the majority of the population (Thörn 2008).

Spain and France experienced criminal prosecution of squatting with significantly different outcomes. While the French case is close to the German one due to the urgent negotiations imposed by authorities after every squatting occurs, some special conditions apply, such as a legal exception that avoids evictions during the winter term (Aguilera 2010; Colin 2010). An equivalent light restriction applies in Spain when judges are not able to clearly identify who has effectively squatted and who has the will to remain in order to obtain the possession of the squatted building (Baucells 1999; Martínez 2002:84-94). Thus, even when evictions increased after 1995 (when the criminal law was passed on), few people were finally sentenced to jail. The Netherlands is experiencing a new situation after the criminalisation of squatting in 2010. Nowadays squatting is still possible and encouraged by political organisations (KSU/Kraakspreekuur), which were more abundant and active in the past (Uitermark 2004b). However, new squats are more rapidly evicted by authorities. There, squatters enjoy the heritage of thousands of squatted places took over in the past decades when there was a greater tolerance. Squatting was legal in the case of liveable buildings left vacant for more than 1 year and, crucially, in case the owner had no ready-to-act plan for the building. This legacy, the accumulation of experiences, can be sharply reduced but cannot be easily destroyed in the short run (Owens 2009; Pruijt 2010b). The UK is the sole European country that still fits the third category, although the coalition of conservatives and liberals in the central government intends to legislate against squatting following the path of the Dutch government (SQUASH 2011). Yet squatting is encouraged by veteran organisations like the Advisory Service for Squatters, based in London, who currently publishes updated versions of the celebrated Squatters Handbook (http://www.squatter.org.uk/). In addition, not only should the legal framework be not too restrictive (conditions " $\mathrm{b}$ " and " $\mathrm{c}$ ") to allow a certain degree of squatting (to open a building and remain for some weeks or months, at least), but also the judicial machine and the police repression must not act too fast and in an inefficient manner so that squatters can risk part of their assets to defy the law. 
Since I contend that squatting in Europe is deployed as an urban movement and this is more than the sum of individual squatting actions, I suggest a fourth condition of possibility which, in fact, points out to a specific feature of this movement: the connection to other social movements. To some extent, squatters take advantage of the experience of previous social movements (hippies, provos, anarchists, punks, environmentalists, citizen struggles, etc) as well as joining many different current social movements (animal rights, hacktivism, solidarity with migrants and precarious workers, queer and trans-feminism, biking, antifascism, artivism, urban ecology, etc). This occurs more often in the squatted social centres, but housing activists are often engaged in these political networks too. These ties allow the emergence of squatting as an urban movement beyond isolated episodes of squatting because they push squatters to pursue multiple goals of social change beyond the right to a free or affordable (mostly urban) space. This is a common ingredient of radical left and countercultural movements (Koopmans 1995:21, 32-35; Rucht 1990) in contrast to the single-issue orientation attributed to other new social movements, such as environmentalists, women and pacifists (Offe 1985).

Global (or, better, alter-global) concerns and the contestation of liberal democracies and capitalism are usually claimed by squatters (Martínez 2007; Notes from Nowhere 2003; Wakefield and GRRRT 1995). This implies a coexistence of local and global perspectives. Each squat has local-urban roots in a specific neighbourhood. Squatting is, thus, an end itself once it is publicly claimed and defended. Without losing this local ground, squatting is also a means to foster other local protests, but some more general class and global struggles too. Tactics and strategy, then, reinforce each other. This discourse pervades the public face of most political squatters, but it is not necessarily accepted or reproduced by many of the different groups who squat or participate in squats. Among the internal diversity of squatters, some can emphasise squatting only as an ends, while others emphasise squatting solely as a means. In addition, these different political identities within the movement are imbricated with context factors relating to the city or the world at large. The easiest way of discovering this imbrication is attending to the multiple connections that squatters have with other alternative or counter-cultural social movements (see Figure 1). The latter, as I will argue later, is well proven when "social centres" acquire a prominent visibility within and outside the movement (Hodkinson and Chatterton 2006; Martínez 2004; Membretti 2007; Mudu 2004).

A final strand of the constitution of an autonomous urban movement is independence from political parties, labour unions, formal organisations, private companies, State bureaucracies, professionals and mass media (Castells 1983; Mayer 2006; Toret et al 2008). This does not mean a complete impermeability or the absence of any mutual links. Every group of squatters has the power to define a proper strategy in order to defend their stay (Martínez 2010). To pay an attorney is a typical forced participation in the State apparatus, even though some squatters also refuse to do it. Alternative and independent media are preferred over commercial media, but all means are likely to be used when tension is at its peak. In case of negotiations, punctual contacts with and support from friendly political parties and civil society associations can be extremely helpful. The effective autonomy of the movement, then, resides in this unstable balance. On the one hand, squatters need 


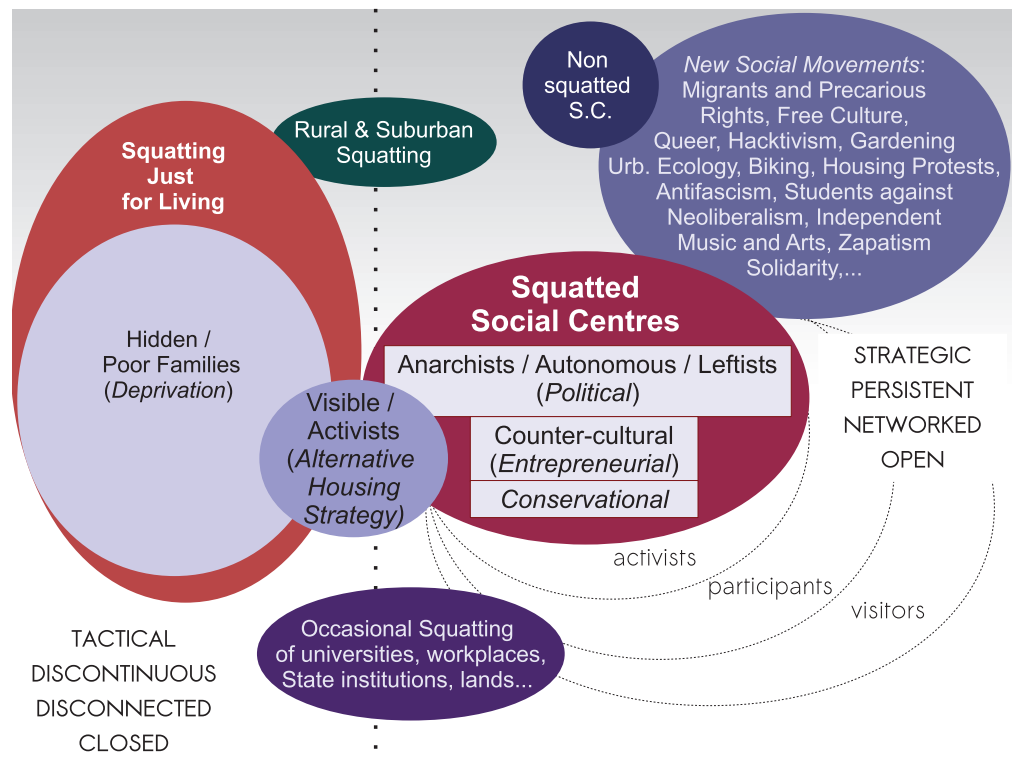

Figure 1: Types of squatting and autonomous-radical orientation of the squatters' movement (source: author). Note: the circle of "new social movements" is just an indication of some of the social and political connections that squatters may keep, although this does not imply that all the members of those movements participate in the squatters' movement or support squatting; the same may be applied to some non-squatted social centres which may also be supportive of squatters and may advocate squatting.

to sustain the squat to strengthen the internal cooperation among activists and sympathisers, and the transmission of experience from pioneers to newcomers. On the other hand, the weakness of ties and resources of the core group-although surrounded by thousands of participants, users, visitors, friends, other movements' militants and supporters (Moroni and Aaster 1996)_requires occasional alliance with more stable social structures (Tarrow 1998).

Accordingly, a regular and not too aggressive mass media coverage, even if it treats squatters with some unfair stereotypes, may help legitimate the autonomy and purposes of this struggle in the eyes of a wide audience. When the mass media offer a window for news about squatting, their basic contribution is to spread some of the existing cases and examples of squatting. These evidences of squatting may appear surrounded by controversies and opinions contrary to the squatters, although the message "squatting is possible (and, often, effective)" cannot be avoided. In the case of squatting-friendly journalists, short stories of squats and living experiences of squatters also allow the general public to understand their motivations. Given the unusual and variable treatment of squatting by the commercial mass media, squatters themselves tended to be actively engaged in the promotion of their own identity through independent media, graffiti, stencils, banners, face-to-face communication, documentaries and self-published books. ${ }^{6}$ While these communicative practices enhance the autonomy of squatters in their public presentation and legitimation, at the same time they put them in close contact with specific social movements dealing with alternative information. 


\section{What is Squatting For?}

In this section I want to look briefly at the beneficial consequences of squatting for squatters themselves, but also for other social groups and for the democratic quality of urban politics in general. Following Pruijt's (2004a, 2012) classification I have associated the autonomy and radicalism of the squatters' movement with the strategic, persistent, networked and openness tendencies of the initiatives and circles of people involved (see Figure 1).

Squatted social centres are placed in the centre of the graph because they accomplish two crucial functions ${ }^{7}$ for the constitution of the squatters' movement: they provide a public resource for meetings, information, leisure, expression and sociability which are essential both to get in touch with kindred people and to launch new squats; beyond its value as a material infrastructure for activists, squatted social centres are the most visible examples of squatting (for public opinion, mass media, local authorities and neighbours), and the most open to recruit new activists, and attract participants, visitors and sympathisers with lesser degrees of commitment. As mentioned above, some of the buildings working as social centres host many political discourses and events closely related to other social movements (migrants' and precarious workers' rights, hacktivism and artivism, urban gardens and organic food, etc). They also offer their facilities to different social and political organisations. Some others combine weaker political concerns with a stronger dedication to organising music concerts, workshops or cheap meals and drinks. Artists, militants and several social groups mix together in most of the counter-cultural or entrepreneurial social centres, but they can also split off into more specialised venues. In the case of successful self-employment initiatives (for example, a brewery in an Amsterdam squat or a handmade craft of jewellery in a Barcelona squat) they tend to move out of the squats and to run their own businesses. The documentary film "Creativity and the Capitalist City" (www.creativecapitalistcity.org) shows several examples of the "breeding places" policies in Amsterdam through which some squats were legalised in order to provide work space for artists.

Conservational squatting reclaims and preserves historical sites or urban areas so that squatting of houses, events at the public space and social centres can be combined as in other types of squatted buildings. When residence and social centre coexist within the same building, a neat separation of both activities tends to be established, although the latter usually plays the most visible role in the symbolic legitimation and promotion of squatting as a radical tool for grassroots urban intervention. In Italy, Spain and the UK, activists and scholars sometimes refer to a "social centres movement" (Common Place 2008; Hodkinson and Chatterton 2006; Mudu 2004; Toret et al 2008) more than to an ambiguous squatters' movement as such. Even when social centres are not squatted any more, they can be considered part of the autonomous and squatters' movement/scene if they continue with a similar style of self-management and political priorities.

Social centres often substitute for the lack of established organisations and city coordination of squats. Social networks of activists arise from demonstrations and informal encounters, but social centres add a direct and tangible example of how 
things can be managed collectively, and hopefully, without paying a rent. These valuable outcomes are more difficult to attain for the squats which are taken over just for living space. The lesser squatters are connected among them and with the nodal point of social centres, the lesser their likeliness to stand one by each other, and to create a cohesive and powerful movement. Public visibility is also a bigger challenge for squatted houses than for squatted social centres. These needs can be filled by formal housing organisations who occasionally support squatting, but they also quit supporting that tactic as soon as they get subsidies or accessible social housing for their members (Aguilera 2010; Bailey 1973; Corr 1999; Pruijt 2003).

Radical squatters do not always expect to squat during the entirety of their lives; this is, in fact, very unlikely (De Sario 2009; Llobet 2005; Owens 2009; Wakefield and GRRRT 1995). For most people who squat for living, squatting is a stage along the way to a permanent residence. The more deprived they are in the housing market, the more they are likely to consider squatting as a tactical political tool or means (illegal immigrants in France, for example, Bouillon 2009). Groups, organisations and networks of radical activists consider squatting strategically when squatting is for them both means and end. Long-lasting squats, either houses or social centres, offer solid and strategic examples, symbols, of the movement's success, although abundant flows of communication among activists and with the rest of society (ie visibility and networking) equally enhance the squatters' social portrait. The Witboek (White Book) published by Dutch squatters before the ban on squatting in 2010, and a recent publication made by a squatting advocacy group from UK facing a similar threat (SQUASH 2011) constitute excellent responses to the strategic challenge of communicating the goal that nurtures the core of this movement:

Over the past three months the government have been undertaking a consultation process entitled 'Options for Dealing with Squatters' which came to an end on October $5^{\text {th }}$ [2011]. Squatters Action for Secure Homes (SQUASH) have accused the government of 'ignoring the consultation' by rushing through anti-squatting laws only three weeks after the consultation has ended. The squatting consultation response has just been published. $90 \%$ of responses argued against taking any action on squatting. Of a total of 2,217 responses, 2,126 were from people concerned about the impact of criminalising squatting. The consultation response recognised 'that the statistical weight of responses was therefore against taking any action on squatting'. The amendment states that making squatting in residential building a criminal offence will 'end the misery of home-owners whose properties have been preyed on by squatters'. However strong legislation already exists to protect residents from having their home squatted. Last month 160 leading legal figures wrote an open letter which was published in The Guardian explaining that under Section 7 of the Criminal Law Act 1977 it is already a criminal offence to squat someone's home. SQUASH spokesperson Paul Reynolds, said: 'The government is ignoring the results of its own consultation which shows that the criminalisation of squatting in empty residential properties will do nothing to protect residents who are already protected by strong legislation. This amendment will criminalise the homeless in the middle of a housing crisis who use squatting as the last remaining option to keep a roof over their heads.'..." (SQUASH 2011: http://www.squashcampaign.org/).

As mentioned before, squatters may combine housing and sociopolitical purposes in the form of a "social centre" within the same building or in separate ones. When 
the residential purposes are the priority, Pruijt (2004a, 2012) has distinguished between "deprivation-based squatting" and "squatting as an alternative housing strategy". While the former involves organisations who help homeless people and migrants to be hosted in a squat, the latter is defined by the self-help of activists and middle-class people in order to solve their own housing needs. Pruijt argues that both types are politically embedded: "a protest against government inefficiency and insensitivity ... empowerment is an element in counterculture and countercultural politics" (Pruijt 2012a:6, 8). His category of "political squatting", however, refers mostly to actions and groups for whom housing needs are not the priority, but eventual means within broad anti-capitalist strategies. I suggest to add the variable of public visibility and the inclusion of political activists into squatted houses as a way to highlight the political embeddedness of squatting for living. Similar to social centres, those squatted houses where banners and inscriptions are showed in the front walls and windows, among other means to make their illegal status public, are more explicit about their political concerns and goals within the squatting movement than those remaining invisible, hidden or isolated (although invisibility may also be used as a tactical and temporary tool in order to keep safe a political organisation of, say, illegal immigrants). Political squatting is used here, then, in a broader sense than Pruijt's more restricted category. In particular, any explicit defence of squatting, claiming publicly for its legitimacy and using it as a central tool of their practices or as a core element in their political discourse, would fall under that label. Pruijt's approach is quite useful in order to distinguish the different embeddedness into the political realm of different configurations of squatting, but I suggest to add a more holistic approach and consider that a political squatting movement may be made up with the combination of different types of squats, squatters and even non-squatters and non-squatted social centres who share similar concerns, support squatting and are prone to use squatting just in case. In addition, the pursuit of multiple political goals beyond the defence of squatting means that the act of squatting is not always prioritised by these activists. Also, accordingly to Holm and Kuhn's argument, "urban social movements cannot really be understood when considered in isolation, they must instead be viewed against the background of general social change" (2010:11).

With the centrality of squatted, and some non-squatted, social centres and the emerging structures of coordination of squatted houses, we can see some of the least known contributions of squatting to shaping an autonomous arena in urban politics. First of all, squats provide spaces where activists belonging to different social movements can meet. This provision is administered through collective principles of horizontal and direct democracy, self-management, non-bureaucratic regulation or State control (Piazza 2011), and free or cheap access to goods and services. Recycling, dumpster diving and sharing resources show how to live at low cost and to be environmentally friendly in urban settings. Moreover, social centres and squatters' organisations encourage people to experiment with alternative and communal modes of living which are outside of the mainstream of culture, politics, economy and social relationships. Squatting offers immediate results in the practice of direct action and social disobedience against the unjust distribution of wealth. Both by means of creative cultural expressions, and through organised opposition around 
broadly censored issues (police brutality, political corruption, current situation in jails, unfair global trade, etc), squatted places expand the consciousness of their participants into the realm of dissidence, resistance, temporality and uncertainty. According to one publication put out by Barcelona squatters (VVAA 2004 ), squatted socials centres involve "struggles against the destruction of neighbourhoods by speculators", "workshops for collective learning without money", "raising funds for the social centre and other projects", "popular culture", "non-commercial leisure", "assemblies and meetings", "networks of affects and solidarity", "independent and horizontal media communication", and "constructive resistance".

For the homeless, deprived, under-privileged, working-class, unemployed and dropouts of the institutional systems-education, asylums, juvenile homes, etcsquatting forms a key survival tactic and sometimes strategy. Not only can an affordable shelter be conquered, but also one can be actively involved in the satisfaction of basic needs. This is usually achieved thanks to the interaction with wealthier and more skilled individuals, resulting in a clear increase of social capital and mutual learning for all. Most of those engaged in squatting benefit from the empowerment, skills, opportunities and self-confidence that these collective actions entail (Bouillon 2009; Hellström 2006; Llobet 2005; Martínez 2002; Pruijt 2004a, 2004b; Wakefield and GRRRT 1995). It has not been widely recognised that, in comparison to other forms of activism, squatting comprises almost the whole everyday life of the people involved. Domestic tasks, gender relations and the emotional dimensions of activism are regularly tackled, obliging squatters to transform their previous approaches to these questions. Among the skills squatters gain is the capability to deal with their own physical space in the context of urban affairs of the local neighbourhood, the city and the metropolitan area. Private life and communal living demands as much effort as public life and urban struggle, especially in relations with the city councils, officials, politicians, judges, lawyers, private owners, companies, real estate developers, journalists, researchers and all kinds of neighbours, be they in favour of squatters, against them, or seemingly indifferent.

As shown in Table 2, squatted social centres and houses can generate positive social impacts in different proportions and with different combinations, but usually they reinforce each other. While all the cases of squatting share directly a political network, sometimes the squatting movement can also include non-squatted social centres with similar styles of autonomous self-management. These are subjected to different legal and economic constraints than those experienced by squatted social centres and houses, but the former can also help squatters to meet, self-organise and squat. This is in particular the case of anarchist venues owned by individuals or activists (Fundación Aurora Intermitente in Madrid, for example, during the 1980s and 1990s, or the London Action Resource Centre in the present) (Common Place 2008; Wilhelmi 2000). Coherence between political ends and means is better achieved in squats, but the stability (and availability) of legal autonomous spaces may be a valuable means for preparing illegal takes over empty buildings. However, former squats (for example, some of those more arts-oriented in Paris; Aguilera 2010) may reduce the range of their social benefits when they turn into a legal status and, simultaneously, explicitly tend to separate themselves from any type of squatting. Some squatted social centres aiming to get a legal status can both keep close 
Table 2: What is squatting for?

\begin{tabular}{|c|c|c|}
\hline Impact & Types of squatting & Benefits \\
\hline $\begin{array}{l}\text { Spatial } \\
\text { infrastructure }\end{array}$ & $\begin{array}{l}\text { Social centres (SC), communal } \\
\text { houses }\end{array}$ & $\begin{array}{l}\text { Provision of affordable/free space for } \\
\text { meetings, information, } \\
\text { non-commercial leisure, expression } \\
\text { and sociability }\end{array}$ \\
\hline Squatting practices & Visible SC and houses & $\begin{array}{l}\text { Provides examples of successful and } \\
\text { failed squatting, attraction of users, } \\
\text { recruitment of activists, legitimacy }\end{array}$ \\
\hline $\begin{array}{l}\text { Culture and } \\
\text { politics }\end{array}$ & Leftist and entrepreneurial SC & $\begin{array}{l}\text { Organisation of talks, solidarity } \\
\text { events, connection with social } \\
\text { movements, artistic shows, } \\
\text { workshops, cheap meals and drinks }\end{array}$ \\
\hline Urban preservation & $\begin{array}{l}\text { Conservational squatting of houses } \\
\text { and SC }\end{array}$ & $\begin{array}{l}\text { Preservation of historical, } \\
\text { environmental and social } \\
\text { sites/buildings/urban areas, } \\
\text { struggles against speculators }\end{array}$ \\
\hline Housing & $\begin{array}{l}\text { Hidden and visible houses, some SC } \\
\text { with residents }\end{array}$ & $\begin{array}{l}\text { Affordable/free access to empty } \\
\text { houses }\end{array}$ \\
\hline $\begin{array}{l}\text { Democratic } \\
\text { participation }\end{array}$ & SC and some collective houses & $\begin{array}{l}\text { Horizontal and direct democracy, } \\
\text { self-management, non-bureaucratic } \\
\text { regulation, direct action and social } \\
\text { disobedience }\end{array}$ \\
\hline $\begin{array}{l}\text { Natural and urban } \\
\text { environment }\end{array}$ & Most, especially political squatting & $\begin{array}{l}\text { Rehabilitation of buildings, recycling } \\
\text { of food and trash, dumpster diving, } \\
\text { sharing resources, living at low cost }\end{array}$ \\
\hline $\begin{array}{l}\text { Social and cultural } \\
\text { capital }\end{array}$ & $\begin{array}{l}\text { Most, especially visible and political } \\
\text { squatting }\end{array}$ & $\begin{array}{l}\text { Empowerment to solve own needs, } \\
\text { self-help, mutual aid, DIY, care for } \\
\text { domestic life and gender relations, } \\
\text { skills to deal with } \\
\text { authorities/institutions/media/ne- } \\
\text { ighbours }\end{array}$ \\
\hline
\end{tabular}

Source: author

relationships with active squatters and squatting actions, and with legal autonomous social centres as well. This is the case of Patio Maravillas in Madrid, linked to both an autonomist network RES (Rompamos el Silencio) that promoted squatting, and to more stable autonomous and non-squatted social centres (Candela in Terrassa, Casa Invisible in Málaga, and Tabacalera in Madrid, for example) (Martínez 2010: 88-95).

\section{Conclusions}

The main argument in this paper is that the squatters' movement has evolved in Europe during the last four decades as a genuine autonomous urban movement. Its practices around collective consumption, housing shortages and alter-global concerns contributed to the satisfaction of social needs and to strive for the legitimation of a radical democratic approach to urban politics.

During the last decades, most European countries have approved legislation that forbids squatting, with Holland and the UK until recently the most tolerant. At 
the same time this general prosecution of squatting made room for institutional arrangements, allowing some cases to be legalised. However, as I have argued above, favourable legal windows and the particular repressive policies over squatting are only some of the conditions that may allow squatting to emerge. They need to be combined with other favourable conditions, such as a sufficient amount of abandoned properties, the slow rhythm of restructuring and renewal of urban areas, connections and fruitful exchanges with alternative social movements, appeal to rights and exceptions within the legal frameworks and a not too critical coverage by mass media. Autonomy, then, is obtained through the squatters' responses to this socio-spatial framework of opportunities and constraints, by means of their organisational strength, cooperation and internal cohesion.

In addition, the squatters' movement has spread out according to different configurations. Social centres and political squatting, mainly, provided public visibility, political legitimation and strategic urban locations capable of interconnecting the different and specialised forms of squatting. Networks involve both squatted social centres and houses, but also non-squatted autonomous social centres, rural squatting and tactical squatting in general (the occupation of squares, for example). Although ties with other movement organisations tend to be weak, the persistence of the whole network indicates a significant strength based on specific impacts on the urban politics of each city. In particular, squatted social centres constitute accessible, free and independent meeting spaces for many individuals, groups and movements. Besides, the whole domain of everyday life is affected by the collective practices of self-management. Not the least, squatting for living purposes offers affordable housing and empowers people with new skills of self-help and social cooperation, especially if they practice alternative and communal ways of living.

All of these transnational patterns deserve more careful and systematic research. Relevant internal differentiation, the side effects of squatting on urban politics and specific local coalitions with other citizens' and broader social movements can set the future agenda. Nonetheless, new political issues and innovative repertoires of action confronting the ongoing wave of neoliberal urban governance also pave the way for more in-depth insights into the conditions and impacts of the squatters' movement.

\section{Acknowledgements}

A first draft of this article was kindly revised by Alan W. Moore. I am also in debt to all the other members of the SqEK (Squatting Europe Kollective) network for their valuable contributions during the meetings held between 2009 and 2011. Although I am personally responsible for this paper, many of the ideas took form thanks to collective work. Comments and criticisms suggested by anonymous referees were also very helpful in order to clarify and improve my argument.

\section{Endnotes}

1 Political debates about conditions of possibility and beneficial impacts of squatting were checked through the meetings and public talks that SqEK members and activists held between 2009 and 2011 (minutes of these meetings are avaliable online: https://sqek.squat.net/). Indymedia nodes and www.planet.squat.net were also the main sources to verify activists' 
concerns about the aspects I deal with in this article. Finally, I also read anonymous comments to mass media news about squatting and weblogs against squatting (such as http://antiokupas.blogspot.com.es/). However, these questions are also relevant within the anarchist and autonomist heritages that have been very influential in the squatting movement of Italy (Mudu 2009) as well as in other European squatters. From a theoretical point of view, I expect to follow the approaches to 'contentious politics' (Tarrow 1998), 'agonistic dissent' (Mouffe 1993) and the struggle for a just city (Young 1990) among others that may be regarded useful for the political comprehension of the squatters' non-institutional modes of political participation.

2 Deprivation-based squatting, squatting as an alternative housing strategy, entrepreneurial squatting, conservational squatting and political squatting. Pruijt (2012:3) refers to this typology as a set of "configurations", these being a sort of ideal types: "combinations of features that are logically consistent and fit to the environment, and can therefore be expected to be efficient and effective".

3 See also Chatterton's (2002:2) analysis: "Rather than being rooted in the specificities of place, such corporate entertainment infrastructures create nonplace 'corporate playscapes' in cities dedicated to servicing a highly mobile professional service class. Moreover, the increasing corporatisation, purification and privatisation of city centres and their consumption spaces raise concerns for issues of inclusion, diversity and equality. The casualties of this turn towards the corporate entertainment city are the less 'desirable' denizens of urban life -the homeless, the skaters, the goths and punks, the kids hanging out- those, in general, whose do not have consumerism as their main reason for participation in the city."

${ }^{4}$ Most of the legal regulations about squatting have a national scope, but particular stories of repression and negotiation have more to do with the rules and policies of local authorities (Aguilera 2010; Common Place 2008; Martínez 2002:234).

5 Holm and Kuhn (2010:6), however, argue that "the legalizations were only a partial success: by the end of 1984 the squatter movement was finally crushed, or rather, 'pacified'. Only a few legalized houses enjoyed financial support under the 'self-help' programme launched in 1982. In spite of everything, spaces for collective and alternative lifestyles remained a marginal phenomenon. At the same time, the legalization of houses established the division of the movement, making it easier to criminalize the autonomist 'non-negotiators' ... The legalization of houses ultimately signified the end of any political dimension to the squats beyond the scope of housing policy."

6 See, for example, the book published by Kukutza Gaztetxea after their eviction where all the mass media contents are counterbalanced and widely developed with relevant details and favourable opinions of academic experts, rank and file activists, and well known professionals (Kukutza and Egia 2011). Another example is the positive depiction of more than 40 squatted social centres in the metropolitan area of Barcelona just to offer an easy and simple introduction to the reader about their main features and activities (VVAA 2004). Wakefield and GRRRT (1995) also opt for the presentation of short stories and interviews in the UK, while Velleità Alternative (1995) combines pictures, interviews, manifests and political calls to "build up the social centres movement" in Italy. A different independent project is the "House Magic: Bureau of Foreign Correspondance" (four issues) collection of dozens of European experiences, texts, photographs and artistic productions, made by the art historian Alan Moore with a copy-left license (http://occuprop.blogspot.com.es/ and https://sites.google.com/site/housemagicbfc/about).

7 When referring to "functions" I am not pretending to establish a causal or linear relationship between squatted social centres and the rest of relevant social phenomena within squatting. Rather, I just want to emphasise the central node of the social centres within the squatters' movement. Social legitimacy, visible activities, primary access and sociability are better and more likely achieved through social centres, but they can also be performed solely through few cases or through a coordinated network of squatted houses. Usually, both squatted social centres and houses reinforce each other and the movement can easily rise. In Spain, for example, while most of the squatted houses remained highly invisible for the neighbours and mass media, the squatted social centres offered publicly the major features and news of squatting as a broadly extended political urban struggle. 


\section{References}

Adilkno (1994 [1990]) Cracking the Movement: Squatting Beyond the Media. New Cork: Autonomedia

Aguilera T (2010) Gouverner l'illegal. les Politiques Urbaines face aux Squats à Paris. Mémoire de recherche, Master Stratégies Territoriales et Urbaines. Paris: SciencePo

Alford R and Friedland R (1985) Powers of Theory: Capitalism, the State, and Democracy. Cambridge: Cambridge University Press

Bailey R (1973) The Squatters. London: Penguin

Baucells J (1999) L'ocupació d'immobles en el nou Codi Penal. In Assemblea diOkupes de Terrassa (ed) Okupació, repressió i moviments socials (pp 63-74) Barcelona: Kasa de la Muntanya-Diatriba

Bookchin M (1998) Social Anarchism or Lifestyle Anarchism: An Unbridgeable Chasm. San Francisco: AK Press

Bouillon F (2009) Squats. Un autre Point de Vue sur les Migrants. Paris: Alternatives

Buchholz T (2011) Creativity and the capitalist city: The struggle for affordable space in Amsterdam. www.creativecapitalistcity.org (last accessed 1 October 2012)

Castells M (1983) The City and the Grassroots. A Cross-Cultural Theory of Urban Social Movements. Berkeley: University of California Press

Chatterton P (2002) Squatting is still legal, necessary and free: A brief intervention in the corporate city. Antipode 34(1):17

Colin B (2010) «Pas de quartier pour les squatters ! »'espace controversé des squats: repères de militance ou repaire de militants? In B Aiosa, $F$ Naït-Bouda and $M$ Thévenon (eds): Repères et Espace(s). De la pluralité à la polysémie (pp 252-266) Grenoble: Presses Universitaires de Grenoble

Collado F (2007) Abriendo puertas. Okupaciones en València 1988-2006. Valencia: La Burbuja

Common Place (2008) What's This Place? Stories from Radical Social Centres in the UK and Ireland. Leeds: University of Leeds, www.socialcentrestories.org.uk (last accessed 1 October 2012)

Corr A (1999) No Trespassing: Squatting, Rent Strikes and Land Struggles Worldwide. Cambridge: South End Press

Della Porta D and Rucht D (1995) Left-libertarian movements in context: A comparison of Italy and West Germany 1965-1990. In J Jenkins and B Klandermans (eds) The Politics of Social Protest: Comparative Perspectives on States and Social Movements (pp 229-273) London: UCL Press

De Sario B (2009) Resistenze Innaturali. Attivismo Radicale nell'Italia degli anni '80. Milan: Agenzia $X$

Fainstein S (1994) The City Builders: Property, Politics, and Planning in London and New York. Oxford: Blackwell

Fainstein S and Hirst C (1995) Urban social movements. In D Judge, G Stoker and H Wolman (ed) Theories of Urban Politics. (pp 181-204). London: Sage

Foucault M (1982) The subject and power. Critical Inquiry 8(4):777-795

Fox P (2010) The last stand of Free Town. The Believer 8(5):3-11

Graeber D (2004) Fragments of an Anarchist Anthropology. Chicago: Prickly Paradigm

Harvey D (1985) The geopolitics of capitalism. In G Derek and J Urry (eds) Social Relations and Spatial Structure (pp 128-163). London: Macmillan

Hellström M (2006) "Steal this place: The aesthetics of tactical formlessness and 'The Free Town of Christiania'." Unpublished PhD thesis, Swedish University of Agricultural Sciences

Herreros T (2004) Movimiento de las okupaciones y movimientos sociales: elementos de análisis para el caso de Cataluña. In R Adell and M Martínez (eds) ¿Dónde están las Llaves? El Movimiento Okupa: Prácticas y Contextos Sociales (pp 129-149). Madrid: La Catarata

Hodkinson S and Chatterton P (2006) Autonomy in the city? Reflections on the social centres movement in the UK. City 10:305-315

Holm A and Kuhn A (2010) Squatting and urban renewal: The interaction of squatter movements and strategies of urban restructuring in Berlin. International Journal of Urban and Regional Research 35(3):644-658 
Holloway J (2006) Negative and positive autonomism, or, Why Adorno? In J Holloway, F Matamoros and S Tischler (eds) Negativity and Revolution: Adorno and Political Activism (pp 95-100). London: Pluto, http://www.johnholloway.com.mx/2011/07/30/negativeand-positive-autonomism/ (last accessed 1 October 2012)

Katsiaficas G (2006) The Subversion of Politics: European Autonomous Social Movements and the Decolonization of Everyday Life. Oakland: AK Press, http://www.eroseffect.com (last accessed 1 October 2012)

Knabb K (1997) The Joy of Revolution. http://www.bopsecrets.org/PS/index.htm (last accessed 1 October 2012)

Koopmans R (1995) Democracy from Below: New Social Movements and Political System in West Germany. Colorado: Westview

Kukutza G and Egia L (2011) Ellos por Dinero, Nosotras por Placer [They're for money, We're for joy]. Tafalla: Txalaparta

Llobet M (2005) "L'Okupació com Espai-s de Creativitat Social." Unpublished PhD thesis, Universitat de Barcelona

Lowe S (1986) Urban Social Movements: The City After Castells. London: Macmillan

Martin J and Moroni P (2007) La Luna Sotto Casa. Milano tra Rivolta Esistenziale e Movimenti Politici. Milano: Shake

Martínez M (2002) Okupaciones de Viviendas y Centros Sociales. Autogestión, Contracultura y Conflictos Urbanos. Barcelona: Virus

Martínez M (2004) Del urbanismo a la autogestión: una historia posible del movimiento de okupación en España. In R Adell and M Martínez (eds.) ¿Dónde están las Ilaves? El movimiento okupa: prácticas y contextos sociales (pp 61-88). Madrid: La Catarata

Martínez M (2007) The squatters' movement: Urban counter-culture and alter-globalization dynamics. South European Society and Politics 12(3):379-398

Martínez M (2010) Los procesos de institucionalización en el movimiento de okupaciones. Estrategias, discursos y experiencias. In M Domínguez, M Martínez and E Lorenzi (eds) Okupaciones en Movimiento. Derivas, Estrategias y Prácticas (pp 53-132). Madrid: Tierra de Nadie

Martínez M (2011) The citizen participation of urban movements in spatial planning: A comparison between Vigo and Porto. International Journal of Urban and Regional Research 35(1):147-171

Mayer M (1993) The career of urban social movements in West Germany. In R Fisher and J Kling (eds) Mobilizing the Community: Local Politics in the Era of the Global City (pp 149-170). London: Sage

Mayer M (2003) The onward sweep of social capital: Causes and consequences for understanding cities, communities and urban movements. International Journal of Urban and Regional Research 27(1):110-132

Mayer M (2006) Manuel Castells' The City and the Grassroots. International Journal of Urban and Regional Research 30(1):202-206

McKay G (ed) (1998) DiY Culture: Party and Protest in Nineties Britain. London: Verso

Membretti A (2007) Centro Sociale Loncavallo. Building citizenship as an innovative service. European Urban and Regional Studies 14(3):255-266

Mikkelsen F and Karpantschof R (2001) Youth as a political movement: Development of squatters' and autonomous movement in Copenhagen, 1981-95. International Journal of Urban and Regional Research 25(3):609-628

Mitropoulos A (2007) Autonomy, recognition, movement. In S Shukaitis and D Graeber (eds) Constituent Imagination: Militant Investigations / Collective Theorization (pp 127-136). Oakland: AK Press

Moroni P and Aaster C (1996) Centri Sociali: Geografie del desiderio. Dati, statisctiche, progetti, mappe, divenire. Milano: Shake

Mouffe C (1993) The Return of the Political. London: Verso

Mudu P (2004) Resisting and challenging neoliberalism: The development of Italian Social Centers. Antipode 36(5):917-941

Mudu P (2009) Where is Hardt and Negri's multitude? Real networks in open spaces. ACME: An International E-Journal for Critical Geographies 8(2):211-244 
Notes From Nowhere (2003) We Are Everywhere: The Irresistible Rise of Global Anticapitalism. London: Verso

Offe C (1985) New social movements: Challenging the boundaries of institutional politics. Social Research 52(4):817-68

Owens L (2009) Cracking Under Pressure: Narrating the Decline of the Amsterdam Squatters' Movement. Amsterdam: Amsterdam University Press

Péchu C (2006) Droit Au Logement. Genèse et Sociologie d'une Mobilisation. Paris: Dalloz

Piazza G (2011) Which models of democracy? Internal and external decision-making processes of Italian Social Centres in a comparative study. Center of Studies on Politics and Society-WP Series 1(1):3-54

Pickvance C (1985) The rise and fall of urban movements and the role of comparative analysis. Environment and Planning D: Society and Space 31(1):33-53

Pickvance C (1986) Concepts, contexts and comparison in the study of urban movements: A reply to Castells. Environment and Planning D: Society and Space 4(2):221-231

Pickvance C (2003) From urban social movements to urban movements. International Journal of Urban and Regional Research 27(1):102-109

Piven F and Cloward R (1979) Poor People's Movements. Why They Succeed, How They Fail. New York: Vintage

Pruijt $\mathrm{H}$ (2003) Is the institutionalisation of urban movements inevitable? A comparison of the opportunities for sustained squatting in New York City and Amsterdam. International Journal of Urban and Regional Research 27(1):133-157

Pruijt H (2004a) Okupar en Europa. In R Adell and M Martínez (eds) ¿Dónde están las llaves? El movimiento okupa: prácticas y contextos sociales (pp 35-60). Madrid: La Catarata

Pruijt H (2004b) Squatters in the creative city: Rejoinder to Justus Uitermark. International Journal of Urban and Regional Research 28(3):699-705

Pruijt H (2007) Urban movements. In G Ritzer (ed) (2007) The Blackwell Encyclopedia of Sociology (pp 5115-5119). Oxford: Blackwell

Pruijt H (2012a) The logic of urban squatting. International Journal of Urban and Regional Research DOI: $10.1111 / \mathrm{j} .1468-2427.2012 .01116 . x$

Pruijt H (2012b) Culture wars, revanchism, moral panics and the creative city. A reconstruction of a decline of tolerant public policy: The case of Dutch anti-squatting legislation. Urban Studies DOI:10.1177/0042098012460732

Rucht D (1990) Estrategias y formas de acción de los nuevos movimientos sociales. In R Dalton and M Kuechler (eds) Los Nuevos Movimientos Sociales. Un Reto al Orden Político (pp 219-243). Valencia: Alfons el Magnànim

Ruggiero V (2000) New social movements and the "centri sociali" in Milan. Sociological Review 48(3):167-185

Sabaté I (2009) "Ein Zuhause. Etnografía del aprovisionamiento de vivienda en el barrio berlinés de Friedrichshain." Unpublished PhD thesis, Universidad de Barcelona, http:// www.tesisenxarxa.net/TESIS_UB/AVAILABLE/TDX-0420109-110715/01.ISM_TESIS.pdf (last accessed 1 October 2012)

SQUASH (Squatters' Action for Secure Homes) (2011) Criminalising the Vulnerable: Why We Can't Criminalise Our Way Out of a Housing Crisis-A Parliamentary Briefing. http://www.squashcampaign.org (last accessed 1 October 2012)

Tarrow S (1998) Power in Movement: Social Movements and Contentious Politics. Cambridge: Cambridge University Press

Tarrow S (2005) The New Transnational Activism. Cambridge: Cambridge University Press

Thörn C (2008) Intervention or the need for a new cultural critique. Art Monitor 5:48-66

Thörn H, Wasshede C and Nilson T (eds) Space for Urban Alternatives? Christiania 1971-2011. Vilnius: Gidlungs Förlag, www.gupea.ub.gu.se (last accessed 1 October 2012)

Toret J, Sansonetti L, Negri A, López S, Tari M, Rivero J, Díaz J, Fernández S, Carmona P, Herreros T, Sánchez R, Sguiglia N (eds) (2008) Autonomía y Metrópolis. Del Movimiento Okupa a los Centros Sociales de Segunda Generación. Málaga: ULEX and Diputación Provincial de Málaga

Uitermark J (2004a) The co-optation of squatters in Amsterdam and the emergence of a movement meritocracy: A critical reply to Pruijt. International Journal of Urban and Regional Research 28(3):687-698 
Uitermark J (2004b) Framing urban injustices: The case of the Amsterdam squatter movement. Space and Polity 8(2):227-244

Various Authors (2004) Centres Socials Okupats. Una Historia de Resistències, Vides i Lluides. Barcelona: underground edition

Velleità Alternative (1995) 10 settembre 1.9.9.4. Imagini, Voci, Punti di Vista. Per l'Antagonismo del Centri Sociali. Torino: Velleità Alternative

Villasante T (1984) Comunidades Locales. Análisis, Movimientos Sociales y Alternativas. Madrid: IEAL

Vitale T (ed) (2007) In nome di chi? Partecipazione e rappresentanza nelle mobilitazioni locali. Milano: FrancoAngeli

Wakefield S and GRRRT (1995) Not for Rent: Conversations with Creative Activists in the UK. New York: Evil Twin

Wates $\mathrm{N}$ and Wolmar C (eds) (1980) Squatting: The Real Story. London: Bay Leaf Books

Wilhelmi G (2000) Armarse sobre las Ruinas. Historia del Movimiento Autónomo en Madrid (1985-1999). Madrid: Potencial Hardcore

Young I (1990) Justice and the Politics of Difference. Princeton: Princeton University Press 